УдК 340.132.1:796(477)

\author{
М. Д. Василенко
}

\title{
РОЗВИТОК СПОРТИВНОГО ПРАВА ЯК НЕОБХІДНА УМОВА ФОРМУВАННЯ ЄВРОПЕЙСЬКИХ СТАНДАРТІВ СПОРТИВНОГО ВИХОВАННЯ (ОСВІТИ): ЗАГАЛЬНОНАУКОВІ АСПЕКТИ
}

Постановка проблеми. Не викликає сумнівів той факт, що спорт став однією з найважливіших сфер суспільного життя, виступаючи як засобом підвищення життєстійкості та працездатності людей, так і засобом різного роду маніпуляцій. У той же час нормативна регламентація суспільних відносин у сфері спорту в більш-менш розвинутих країнах посідає важливе місце у діяльності органів державної влади та суспільства в цілому. Так, ст. 49 Конституції України проголошує, що держава, поміж іншого, дбає про розвиток фізичної культури і спорту [1]. Нормативне визначення спорту прописано у профільному Законі України «Про фізичну культуру і спорт», який визначає правові, організаційні та соціально-економічні засади розвитку спорту та фізичної культури [2]. Отже, значення спорту для сучасного суспільства спонукає до удосконалення його правового регулювання. Відбувається генезис розвитку структури як самого спорту, так і розширення його функцій, що, своєю чергою, обумовило потребу формування нової самостійної комплексної галузі права - спортивного права. Втім, слід відзначити, що протягом останньої чверті століття відбувається такий принциповий процес в галузі спорту як його суттєва комерціалізація. Саме вона, значною мірою, вплинула на збільшення обсягу правовідносин, які виникають у спорті та пов'язаних з ним процесах. При цьому виникають суперечливі питання, що вимагають розв'язання у правовій площині шляхом прийняття нових нормативно-правових актів та створення нових інституційних установ. Розвиток спортивного права вимагає підготовки нових спеціалістів. Для впорядкування всіх правовідносин, що виникають у сфері спорту, низкою фахівців, у тому числі й автором цієї роботи вважається за доцільне виділення спортивного права в окрему галузь права (див. [3-5]). У роботі [6] автором (М.В.) завдяки аналізу методологічних аспектів розвитку спорту і права доведено існування спортивного права в Україні як самостійної галузі права. У США, країнах-членах $Є С$ ще 
з 1990-х рр. спортивне право було виокремлено як самостійна комплексна галузь права. У підтвердження цього доречно зауважити, що в цих країнах навчальні заклади на сьогодні готують профільних фахівців, створені різні спортивні судові інстанції тощо, на що звертав увагу автор цієї роботи при обгрунтуванні становлення спортивного права як галузі правової науки.

Метою статті є виявлення загальнонаукових аспектів розвитку спортивного права та визначення його генезису як галузі юридичної науки в контексті формування стандартів спортивного виховання різних верств населення.

Виклад основного матеріалу. Знаковою прикметою сучасного суспільства став потужний розвиток спортивного шоу-бізнесу (спортивних ігор), в який інвестуються величезні кошти, викликаючи необхідність створення системи правових норм, які регулюють спортивні правовідносини. Такі правові норми, конкретизуючи правовідносини, передбачають впровадження визначеної нормативної регламентації правового статусу спортсмена, процедури спортивного арбітражу, особливостей захисту прав та інтересів суб'єктів спортивних правовідносин тощо. Розуміння сукупності всіх складових частин спортивного права визначає конкретний предмет його регулювання як сукупності суспільних відносин, які виникають і реалізуються в процесі організації та формування спортивного професійного середовища, в тому числі формування спортивних команд, встановлення вимог до професійних спортсменів, а також під час проведення контролю за дотриманням спеціальних правил (регламентів). Очевидно, що в цьому сенсі коло правовідносин, що охоплюється сферою спортивного права, стає доволі широким та має яскраво визначену комплексну спрямованість. Воно включає в себе [7]:

- спорт і фізична культура як об’єкт правового регулювання;

- організаційно-правові основи державного управління фізичною культурою і спортом;

- правове регулювання професійного спорт;

- правове регулювання сфери студентського спорту;

- правове забезпечення суспільних фізкультурно-спортивних об'єднань;

- правовий статус спортсменів, тренерів та інших учасників спортивної діяльності;

- правові засади організації та проведення спортивних змагань;

- регулювання податкових відносин у сфері спорту;

- право інтелектуальної власності у сфері спортивної діяльності;

- правове регулювання дитячо-юнацького спорту.

До предмету спортивного права також, безумовно, слід віднести суспільні відносини у сфері спортивного арбітражу (медіаціі), спортивної відповідальності як специфічного виду юридичної відповідальності, спортивного суддівства, а також відносини міжнародного співробітництва у галузі спорту. Останнє положення набирає актуальності у зв'язку з тим, що останнім часом міжнародний менеджмент щодо спортивних ігор використовується як засіб політичного впливу та тиску. 
Раніше в роботі [5] автор приводив аргументи та акцентував увагу науковців на тому, що спортивне право знаходиться на стику багатьох галузей права. Це викликано тим, що висока соціальна значущість спорту зобов'язує створити для цієї сфери діяльності відповідні всеохоплюючі правові основи. Очевидним стає та обставина, що в правовій системі України складається значний масив правових приписів, який поєднує в собі норми конституційного, адміністративного, цивільного та інших галузей права. Тим самим спортивне право регулює досить різноманітні правовідносини за участю суб'єктів спортивної діяльності: спортсменів; клубів; організаторів змагань; продавців трансляцій змагань; постачальників спортивного устаткування; продажу сувенірної продукції тощо. Відносини між цими суб'єктами можна віднести до спортивних правовідносин, які регулюються різними галузями права у широкому сенсі слова.

Можливо, про спортивне право слід говорити як про галузь законодавства, яке складається, подібно до військового або медичного законодавства. Можна допустити, що саме спортивне право або його частина (олімпійське право) склалося і як галузь законодавства, і як галузь права. Однак при цьому важко виділити ознаки регулювання спортивним правом суспільних відносин. Специфіка спортивного права багато в чому полягає в тому, що у всьому світі відносини, пов'язані із спортом, регулюються нормами так званого «м'якого права» [8]. Це статути, регламенти і правила федерацій, спортивних асоціацій та інших організацій суто корпоративної власності. Ці норми регулюють відносини суб'єктів спортивного права деколи ефективніше, ніж норми, що продуковані державою у вигляді законів і підзаконних актів.

В Україні нормативну основу виникнення, зміни та припинення спортивних правовідносин складає вже зазначений вище Закон України «Про фізичну культуру і спорт» в редакції 2009 року з чисельними змінами [2] (в першій редакції Закон був прийнятий ще у 1993 році ), а також Закон України «Про антидопінговий контроль у спорті» 2017 року [9]. Згідно із ст. 2 Закону України «Про фізичну культуру і спорт» «законодавство базується на Конституції України і складається із цього Закону, відповідних міжнародних договорів України та інших нормативно-правових актів, що регулюють правовідносини у цій сфері». Однак дослівне тлумачення змісту наведеної норми вказує на відсутність єдиного концептуального нормативно-правового акта, дія якого здатна врегулювати різні аспекти спортивних правовідносин.

У ст. 4 Закону України «Про фізичну культуру і спорт» [2] визначено засади державної політики у сфері фізичної культури і спорту. Зокрема, йдеться про те, що визнання фізичної культури і спорту є пріоритетним напрямом гуманітарної політики держави, а спорт визнається як важливий чинник досягнення фізичної та духовної досконалості людини, формування патріотичних почуттів у громадян та позитивного міжнародного іміджу держави. Більше того, держава забезпечує підтримку громадських організацій фізкультурно-спортивної спрямованості та орієнтується на 
сучасні міжнародні стандарти у сфері фізичної культури і спорту, поєднання вітчизняних традицій і досягнень із світовим досвідом у цій сфері. Відзначається, що державне управління фізичною культурою і спортом (ст. 5) здійснюється центральним органом виконавчої влади у сфері фізичної культури і спорту за сприяння інших органів державної влади та органів місцевого самоврядування.

До сьогодні актуальними залишаються питання про вирішення спорів у спорті та встановлення відповідних критеріїв оцінки діяльності в означеній сфері [10]. Так, відомо, що ст. 45 Закону України «Про фізичну культуру і спорт» передбачає, що вирішення спорів, які виникають між суб'єктами у сфері фізичної культури і спорту, здійснюється відповідно до закону постійно діючим спортивним третейським судом. Адже більшість національних спортивних федерацій в Україні не мають ані спеціалістів 3 розгляду спортивних спорів, ані створених у структурі федерації органів з вирішення таких спорів (квазіарбітражних органів). Прикладом мала би бути Федерація футболу України, яка включає в себе також дві інстанції дисциплінарних органів (Контрольно-дисциплінарний комітет та Апеляційний комітет) та окрему Палата з вирішення спорів між клубами та футболістами. Однак для більшості інших федерацій такий стандарт залишається практично недосяжним. Наразі для вирішення дисциплінарних питань існують уповноважені виконавчі органи федерації, а переглядати їх можуть тільки вищестоящі органи управління - конгреси чи конференції.

Спортивні федерації були і залишаються громадськими організаціями, в складі яких іноді немає навіть юриста, вже не кажучи про спортивного юриста зі знанням англійської мови й практичним досвідом роботи, адже всі документи та рішення квазіарбітражних спортивних органів публікуються англійською мовою [11]. Якщо ж такий спеціаліст є, то він займається питаннями федерації у другорядному порядку, маючи, звісно ж, основну роботу, а тому говорити про якісний та неупереджений розгляд справ не завжди правильно. Крім того, досить часто керівні посади таких органів займають люди з юридичною освітою, але вони не мають досвіду роботи у сфері спорту, не орієнтуються у специфіці, результатом чого стає ухвалення несправедливих рішень або таких, що суперечать регламентним нормам міжнародних федерацій з видів спорту.

Отже, з урахуванням цього очевидною є необхідність створення спеціалізованого суду, в складі якого повинні були саме кваліфіковані юристи-спеціалісти сфери спортивного права. На жаль, в Україні таких спеціалістів мало. Потрібно, щоб вони професійно та незалежно, неупереджено розглядали спірні питання і переглядали рішення спортивних федерацій 3 можливістю подальшого оскарження в Спортивному арбітражному суді (САC). САC (англ. - Court of Arbitration for Sport (CAS), a фр. - Tribunal Arbitral du Sport (TAS)) представляє собою міжнародний арбітражний орган, який вирішує спори, що мають відношення до спорту [12]. Штаб-квартира цього суду знаходиться в Лозані (Швейцарія). У 1996 році були створені відділення суду в США. Акцентуємо увагу на тому, що САС все ж 
таки є справжнім арбітражним судом у сенсі тлумачення положень національного законодавства. Фактично він $€$ незалежним та компетентним, тому внесення спортивною федерацією арбітражного застереження у свої нормативні документи не є зловживанням; САС забезпечує дотримання прав сторін (насамперед, спортсменів) і справедливий розгляд спорів; арбітражне застереження дійсне, навіть якщо право на звернення до суду загальної юрисдикції, передбачене Конституцією, обмежене. Рішення САС виконуються в порядку, передбаченому Конвенцією ООН «Про визнання та приведення у виконання іноземних арбітражних рішень» 1958 р. (тобто рішення САС не може бути переглянуто місцевим судом, воно не потребує додаткового рішення місцевого суду для виконання). Окрім того, до процедури виконання рішень САС у порядку Конвенції справа і не доходить спортивні федерації мають настільки дієвий та сильний апарат адміністративного примусу, що це просто не є потрібним. Рішення САС автоматично й добровільно виконуються міжнародними та національними спортивними асоціаціями, спортсменами, організаторами змагань тощо. Рішення ж національного суду виконується у всім відомому порядку. При цьому судді не $є$ професіоналами у сфері спорту, розгляд справ тягнеться роками. Проте іноді, якщо мова йде про спір між спортсменом та національною федераці$€ ю$, арбітражне застереження щодо САС відсутнє, і спортсмени звертаються до судів загальної юрисдикції. Окрім того, вартість звернення до суду загальної юрисдикції набагато нижча для спортсменів, аніж звернення до CAC, навіть за умови отримання спортсменом правової допомоги. Важливо відзначити, що рішення САС може бути переглянуте або скасоване лише Верховним федеральним судом Швейцарії, місцеві (національні) суди не мають юрисдикції з перегляду та скасування рішень САС. Натомість їхня роль зводиться до визнання та виконання рішень САС у порядку, передбаченому вищезгаданою Конвенцією. Національний суд може відмовити у визнанні та виконанні рішення САС, якщо таке виконання суперечитиме публічному порядку країни цього суду.

Підсумовуючи зазначене вище, підкреслимо, що коли правила міжнародної федерації вступають у конфлікт 3 рішеннями національних судів, національна федерація (або спортсмен) знаходяться «між двох вогнів» рішенням місцевого суду і рішенням міжнародної федерації, які часто можуть бути діаметрально протилежними. Однак треба завжди мати на увазі, що рішення національного суду або третейського суду завжди обмежене його юрисдикцією, тобто країною. Коли спортсмен чи федерація не підпадають під юрисдикцію такого суду, його рішення не може бути виконане. У зв'язку із цим Національний олімпійський комітет (HOK) України вже займається питанням створення спортивного третейського суду в Україні: розроблені та ухвалені регламентні документи, формується можлива палата суддів, і справа лише за реєстрацією такого третейського суду [11]. Однак Закон України «Про фізичну культуру і спорт», незважаючи на своє значення, має суттєвий недолік. Він ніяким чином не систематизує норми спортивного права, як це зроблено в кодифікованих галузевих актах. 
Такий стан речей ускладнює регулювання спортивних правовідносин, породжує затвердження неоднорідних вимог до одних і тих самих відносин.

Принциповим залишається ще одне нерозв'язане питання. Спортивне право як самостійна галузь права тісно пов'язане з рівнем розвитку спортивного руху в Україні, який за нормальних умов може забезпечити економічний (особливо у сфері інвестування, туризму), соціально-культурний (зростання національної самоідентифікаціі) та інший розвиток держави. Принциповим суттєвим ускладненням розвитку спорту в Україні є те, що Верховною Радою України досі не ратифіковано низку міжнародно-правових договорів у сфері спортивного права (наприклад, Кодекс спортивної етики, Кодекс спортивного арбітражу). Це породжує неможливість звернення суб'єктів спортивних правовідносин в Україні до САС, оскільки в країні відсутні відповідні інституції.

У контексті обговорення зазначеної теми слід звернути увагу на документ десятирічної давнини - «Державну програму розвитку фізичної культури і спорту на 2007 - 2011 роки» (програма була затверджена Постановою Кабінету Міністрів України ще в 2006 році) [13]. У цій програмі прописані основні причини, що гальмують розвиток спорту в Україні, і з того часу принципових змін не відбулося. А саме відзначалися такі негаразди, як недосконала нормативно-правова база регулювання спортивних правовідносин; відсутність уніфікованих правил функціонування спортивних організацій тощо. Крім того, в документі вказувалось про відсутність необхідної інфраструктури для проведення міжнародних спортивних змагань.

В Україні за останні роки в питанні правового регулювання щодо професійного спорту відбулися помітні покращення. Відмітимо, що в березні цього року було прийнято постанову Кабінету Міністрів України № 115 «Концепція Державної цільової соціальної програми розвитку фізичної культури та спорту на період до 2020 року» [14].

Концепція Програми була схвалена розпорядженням Кабінету Міністрів України від 9 грудня 2015 р. № 1320 [15].

Слушно відзначити, що метою Програми є надання фізичній культурі та спорту в Україні провідної ролі як важливого чинника здорового способу життя, профілактики захворювань, формування гуманістичних цінностей, створення умов для всебічного гармонійного розвитку людини, сприяння досягненню фізичної та духовної досконалості людини, реалізації резервних можливостей організму людини, формування патріотичних почуттів у громадян і позитивного іміджу держави в світовій спільноті.

Очікується, що виконання Програми дасть можливість:

- підвищити рівень обхвату населення руховою активністю на 1-2 відсотки щорічно;

- створити умови для соціальної адаптації і реабілітації інвалідів і осіб з обмеженими фізичними можливостями;

- підвищити рівень готовності молоді до служби в Збройних Силах та в інших військових формуваннях, визначених законам, правоохоронних 
органах, рятувальних і інших спеціальних службах із метою захисту суверенітету і незалежності держави;

- підвищити рівень зацікавленості дітей і молоді в соціальних, профілактичних акціях, направлених на мотивацію свідомого відношення до власного здоров'я;

- підвищити рівень інформованості і обізнаності різних груп населення щодо формування здорового способу життя і профілактики негативних явищ серед дітей і молоді;

- забезпечити надання якісних фізкультурно-спортивних послуг спортивним клубам і фізкультурно-оздоровчими закладами, які функціонуватимуть відповідно до встановлених стандартів;

- привернути до 13 відсотків дітей і молоді у віці від 6 до 18 років до занять в дитячо-юнацьких спортивних школах, створити умови для розвитку резервного спорту і ефективного поповнення складу національних збірних команд;

- забезпечити збереження провідних позицій українських спортсменів у міжнародних змазаннях різного рівня для підняття авторитету держави в світовій спортивній спільноті;

- забезпечити збереження і створення розгалуженої мережі сучасних спортивних споруд (спортивні зали, плавальні басейни, спортивні майданчики і т. д.), які відповідають національним і міжнародним стандартам, зокрема із залученням засобів інвесторів;

- забезпечити підвищення професійних знань, професійного рівня i вміння працювати в нових соціально-економічних умовах, а також здійснення контролю за станом здоров'я, профілактикою травматизму, захворювань і якістю тих, що надаються медичних послуг.

Фінансування Програми планується здійснювати за рахунок засобів державного бюджету, інвестицій і інших джерел, не заборонених законодавством.

Як юрист, який добре знайомий 3 різними галузями права в різних правових системах, зазначу, що в нашій країні існує хибна точка зору про те, що у разі виділення спортивного права у правовій системі України може виникнути негативна практика подрібнення вже сформованих галузей права: конституційного, адміністративного, трудового, цивільного. Однак, на притивагу існуючим поглядам, виділення спортивного права в самостійну галузь права тільки сприятиме вдосконаленню своєрідних за своєю сутністю і змістом правовідносин, що грунтуються на загальних принципах права, нормах Конституції України, законодавства, що регулює порядок здійснення державного управління в галузі економіки, освіти та спорту. На користь самостійності спортивного права слід охарактеризувати характер правопорушень у цій сфері та відповідальність за їх вчинення. На відміну від законодавства про адміністративні правопорушення та трудового права, законодавство в галузі фізичної культури і спорту передбачає такі санкції, як: дискваліфікація гравця; обмеження участі в матчах, 
турнірах; виключення спортивної команди (клубу) із складу галузевих об'єднань, турнірів, змагань чи обмеження такої участі. Реалізація цих засобів впливу потребує не лише деталізації підстав для їх застосування (складів правопорушень), але і розробки процедури, порядку розгляду і вирішення спорів та порядку застосування таких санкцій у галузі спорту.

3 огляду на становлення нової галузі права виникає питання співвідношення спортивного права із стандартами. Стандарт у широкому сенсі слова представляє собою зразок, еталон, модель, що приймається для зіставлення з ними інших подібних об’єктів. У нашому випадку під стандартом мається на увазі нормативний документ, що встановлює правила, а сам документ відрізняється особливостями розробки, твердження, способів використання, а також спрямованістю на особливу мету. По суті, стандарт можна характеризувати як узгоджений метод виконання чого-небудь. Це може бути виробництво виробу, управління процесом, надання послуги або постачання матеріалів. Стандарти можуть охоплювати широке коло дій і об'єктів. Стандарти є концентрованою мудрістю людей, що володіють експертними знаннями у своїх областях знань і які знають, що є потрібним організаціям, які вони представляють. Йдеться про виробників, продавців, покупців, споживачів, галузеві асоціації, користувачів і законодавців.

3 точки зору права і спорту Україні фактично потрібна модель реформування спорту з урахуванням європейських стандартів. Очевидно, що держава в реаліях сьогодення не здатна управляти спортом: потрібна модель, яка включає автономію спорту. Це означає, що держава повинна діяти за вимогами, які задають федерації, що працюють за стандартами Олімпійської хартії або за хартіями (правилами) міжнародних федерацій. При цьому держава залишає за собою адміністративну функцію - функцію ухвалення рішення. Вона задає державну політику в галузі спорту, але не втручається в такі питання, як : якому спортсмену їхати на змагання; якого кольору надіти форму, які встановити правила тощо. Для того, щоб перейти до реформування, необхідним є усвідомлене рішення, політична воля, ясність і чистота помислів людей, які відповідають за процес реформування. Процес реформування - це проект. Він повинен мати часові межі. Так само виділяється певна сума коштів, яка йде на перенавчання людей, що працювали в тій системі, на створення академічних фундаментів, тому що сьогодні люди бояться реформування, адже вони не знають, як можна жити в інших умовах. Таким чином, не дивлячись на те, що спортивне право в Україні як галузь права практично сформувалась, спортивні стандарти потребують вдосконалення,

Висновки. На сьогодні функції учасників спортивних правовідносин (держава, федерації за видами спорту, органи місцевого самоврядування, клуби, спонсори і меценати, батьки, організатори спортивної роботи в учбових закладах і силових структурах та інші суб’єкти) залишаються 
розмитими, не чітко визначені їх повноваження і відповідальність, що заважає розвитку їх ефективної взаємодії. Цікавим на сьогодні є дослідження правового статусу замовника спортивної послуги, спонсора, мецената у сфері спорту. Таким чином, потребує цілеспрямованого реформування система спортивних правовідносин України, яку необхідно привести у відповідність з нормами Олімпійської хартії, рішеннями Генеральної Асамблеї $\mathrm{OOH}$ і викликами часу. Активну участь в процесі оновлення мають приймати спортивні клуби, об’єднані федераціями, з участю спортивних шкіл всіх форм власності.

\section{Література}

1. Конституція України : Закон України від 28 червня 1996 р. № 254к/96-ВР / / Відомості Верховної Ради України. - 1996. - № 30. - Ст. 14.

2. Про фізичну культуру і спорт : Закон України від 24 грудня 1993 р. № 3808-XII // Відомості Верховної Ради України. - 1994. - № 14. - Ст. 80.

3. Бордюгова Г.Ю. Спортивне право як нова комплексна галузь права / Г.Ю. Бордюгова / / Адвокат. - 2008. - № 8. - С. 13

4. Чередник Р.В. Становлення спортивного права як комплексної галузі в правовій системі України / Р.В. Чередник / / Актуальні проблеми політики : зб. наук. праць. - 2011. - Вип. 42. C. 272 .

5. Василенко М.Д. Становлення спортивного права в Україні як галузі юридичної науки в контексті розвитку міжнародного спортивного права / М.Д. Василенко / / Актуальні проблеми держави і права. - О. : Видавничий дім «Гельветика», 2017. - Вип. 78. - С. 34.

6. Василенко M. Спортивне право: показники його формування (методологічний та учбовий аспекти) / М. Василенко / / Юридичний вісник - Одеса. - 2017. - № 2.

7. Гаро Г.О. Спортивне право: огляд національного законодавства і міжнародних стандартів / Г.О. Гаро, О.О. Кушнір // Протокол : юридичний інтернет-ресурс. - [Електронний pecypc]. - Режим доступу : http://protokol.com.ua/ru/sportivne_pravo_oglyad_natsionalnogo_ zakonodavstva_i_mignarodnih_standartiv/.

8. Заярний О. Спортивне право в Україні. Ознаки самостійної галузі / О. Заярний, А. Куц / / Юридичний Вісник України. - № 50(859), 17-23 грудня. - 2011.

9. Про антидопінговий контроль у спорті : Закон України від 7 лютого 2017 № 1835-VIII / / Відомості Верховної Ради, - 2017. - № 11, - Ст. 102.

10. Гаро Г.О. Особливості медіації конфліктів і суперечок в професійному спорті [Електронний ресурс] / Г.О. Гаро, О.О. Кушнір // Протокол : юридичний інтернет-ресурс [Електронний ресурс]. - Режим доступу : http://protokol.com.ua/ua/osoblivosti_mediatsii_konfliktiv_i_ superechok_v_profesiynomu_sporti/.

11. Бордюгова А. Формування спортивного права як галузі тільки починається / Анна Бордюгова, Єгор Желтухін // Юридична газета. - [Електронний ресурс]. - Режим доступу : http:/ / yur-gazeta.com/interview / formuvannya-sportivnogo-prava-yak-galuzi-tilki-pochinaetsya.html.

12. «O спорт, ты - мир!» Роль международного права, lex sportiva и lex olympica в регулировании международных спортивных отношений. - М. : ГИ «Центральная типография», 2013 [Електронний ресурс]. - Режим доступу : goo.gl/uZ1Ybu.

13. Про затвердження Державної програми розвитку фізичної культури і спорту на 2007-2011 роки : Постанова Кабінету Міністрів України від 15 листопада 2006 р. № 1594 // Офіційний вісник України - 2006. - № 46. - Стор. 45. - Ст. 3078.

14. Концепція Державної цільової соціальної програми розвитку фізичної культури та спорту на період до 2020 року : Постанова Кабінету Міністрів України від 1 березня 2017 № 115 / / Офіційний вісник України. - 2017. - № 22. - Стор. 147. - Ст. 621.

15. Про схвалення Концепції Державної цільової соціальної програми розвитку фізичної культури і спорту на період до 2020 року : Розпорядженням Кабінету Міністрів України від 9 грудня 2015 р. № 1320 // Офіційний вісник України. - 2015. - № 102. - Стор. 163. Ст. 3529 . 


\section{Анот а ці я}

Василенко М. Д. Розвиток спортивного права як необхідна умова формування європейських стандартів спортивного виховання (освіти): загальнонаукові аспекти. - Стаття.

У статті розглядаються загальнонаукові та організаційно-правові аспекти розвитку спортивного права як самостійної галузі права в контексті формування європейських стандартів спортивного виховання. Обговорюється необхідність створення спортивного третейського суду в Україні. Надано рекомендації щодо розробки спортивних стандартів.

Ключові слова: спортивне право, галузь права, законодавство, «м'яке право», виховання, європейські стандарти, спортивні організаціі.

\section{А н н о т и я}

Василенко $H$. Д. Развитие спортивного права как необходимое условие формирования европейских стандартов спортивного воспитания (образования): общенаучные аспекты. - Статья.

В статье рассматриваются общенаучные и организационно-правовые аспекты развития спортивного права как самостоятельной отрасли права в контексте формирования европейских стандартов спортивного воспитания. Обсуждается необходимость создания спортивного третейского суда в Украине. Представлены рекомендации по разработке спортивных стандартов.

Ключевые слова: спортивное право, отрасль права, законодательство, «мягкое право», воспитание, европейские стандарты, спортивные организации.

\section{S u m m a r y}

Vasylenko N. D. Development of sport law as essential condition to forming european standards for sport training (education): generally scientific aspects. - Article.

In the article the generally scientific and organizing legal aspects for development of sport law as the independent branch of law in the context to forming of the European standards for sport education are examined. The necessity of creation of court for sport arbitration in Ukraine is discussed. Recommendations for development of sport standards are given.

Key words: sport law, branch of law, legislation, «soft law», education, European standards, sport organizations. 